\title{
PARAMETERS FOR THE EVALUATION OF CERVICAL SAGITTAL BALANCE IN IDIOPATHIC SCOLIOSIS
}

\author{
PARÂMETROS DE AVALIAÇÃO DO EQUILÍBRIO SAGITAL CERVICAL NA ESCOLIOSE IDIOPÁTICA \\ PARÁMETROS DE EVALUACIÓN DEL BALANCE SAGITAL CERVICAL EN ESCOLIOSIS IDIOPÁTICA

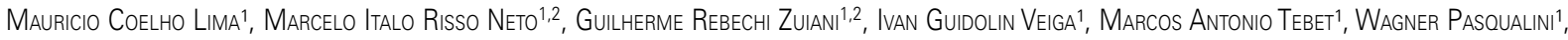 \\ Elcio Landim ${ }^{1,2}$, Paulo Tadeu Maia Cavali ${ }^{1,2}$
}

1. Universidade Estadual de Campinas (UNICAMP), School of Medical Sciences, Department of Orthopedics and Traumatology, Spine Surgery Group, Campinas, SP, Brazil.

2. Hospital Alemão Oswaldo Cruz, São Paulo, SP, Brazil.

\begin{abstract}
Objective: There are no values defined as standard in the literature for the parameters of assessment of cervical sagittal balance in patients with idiopathic scoliosis. This study describes the sagittal cervical parameters in patients with idiopathic scoliosis. Methods: Study carried out in a tertiary public hospital in patients with adolescent idiopathic scoliosis, through the evaluation of panoramic radiographs in lateral view. The Cobb method was used to evaluate cervical lordosis from C2 to C7, distance from the center of gravity (COG) of the skull to C7, measurement of T1 slope, thoracic inlet angle (TIA), neck tilt, and plumb line from C7 to S1 (SVA C7-S1). A statistical analysis was performed, to demonstrate the relationship between the alignment of the thoracic spine in the sagittal plane and the cervical sagittal balance of patients with scoliosis. Results: Thirty-four patients were female (69.4\%) and 15 male (30.6\%). The mean values for COG-C7 were $0.71 \mathrm{~mm}$ (median $0.8 \mathrm{~mm} / \mathrm{standard}$ deviation $[\mathrm{SD}]=0.51 \mathrm{~mm}$ ). For Cobb C2-C7, the mean was $-11.7^{\circ}$ (median $-10^{\circ} / \mathrm{SD}=20.4^{\circ}$ ). The mean slope of $\mathrm{T} 1$ was $23.5^{\circ}\left(\mathrm{median} 25^{\circ}\right.$ $\mathrm{SD}=9.5^{\circ}$ ). The mean cervical version was $58.8^{\circ}$ (median $60^{\circ} / \mathrm{DP}=15.4^{\circ}$ ). The mean TIA was $81.8^{\circ}\left(\right.$ median $85^{\circ} / \mathrm{SD}=16.7^{\circ}$ ). The mean plumb line C7-S1 was $-0.28(-0.3 / S D=1.0)$ Conclusion: The analysis of the results showed that the mean values for the cervical lordosis are lower than the values described as normal in the literature, suggesting a loss of sagittal cervical balance in these patients.
\end{abstract}

Keywords: Scoliosis; Postural balance; Spine.

\section{RESUMO}

Objetivo: Não existem valores definidos como padrão na literatura para os parâmetros de avaliação do equilíbrio sagital cervical em pacientes com escoliose idiopática. Este estudo descreve os parâmetros sagitais cervicais em pacientes portadores de escoliose idiopática. Métodos: Estudo realizado em um hospital público terciário em pacientes com escoliose idiopática do adolescente, por meio da avaliação de radiografias panorâmicas em vista lateral. Utilizou-se o método de Cobb para avaliação da lordose cenvical de C2 a C7, distância do centro de gravidade (COG, center of gravity) do crânio até C7, medida da inclinação de T1 (T1 slope), ângulo da abertura superior do tórax (TIA, thoracic inlet angle), versão cervical (neck tilt) e linha de prumo C7-S1 (SVA C7-S1). Foi realizada análise estatística dos dados obtidos para comprovar de forma objetiva a relação entre o alinhamento da coluna torácica no plano sagital e o equilibrio sagital cervical dos portadores de escoliose. Resultados: Trinta e quatro pacientes eram do sexo feminino (69,4\%) e 15 do sexo masculino (30,6\%). A média dos valores para COG-C7 foi 0,71 mm (mediana 0,8 mm/desvio padrão $[D P]=0,51 \mathrm{~mm})$. Para o Cobb de C2-C7, a média foi $-11,7^{\circ}$ (mediana -10\% $/ D P=20,4^{\circ}$. . A média da inclinação de $T 1$ foi $23,5^{\circ}\left(\right.$ mediana $\left.25^{\circ} / D P=9,5^{\circ}\right)$. A média da versão cervical foi $58,8^{\circ}$ (mediana $60^{\circ} / D P=15,4^{\circ}$ ). A média do TIA foi 81, $8^{\circ}$ (mediana $85^{\circ} / D P=16,7^{\circ}$ ). A média da linha de prumo C7-S1 foi -0,28 (-0,3/DP=1,0). Conclusão: A análise dos resultados obtidos demonstrou que a média dos valores para a lordose cervical é menor do que os valores descritos como normais na literatura, sugerindo uma perda do equilíbrio sagital cenvical nesses pacientes.

Descritores: Escoliose; Equilíbrio postural; Coluna vertebral.

\section{RESUMEN}

Objetivo: No hay valores establecidos como estándar en la literatura para los parámetros de evaluación del equilibrio sagital cervical en los pacientes con escoliosis idiopática. Este estudio describe los parámetros sagitales cervicales en pacientes con escoliosis idiopática. Métodos: Estudio realizado en un hospital público terciario en pacientes con escoliosis idiopática del adolescente, por medio de la evaluación de radiografías panorámicas en vista lateral. Se utilizó el método de Cobb para la evaluación de la lordosis cervical de C2 a C7, distancia del centro de gravedad (COG, center of gravity) del cráneo hasta C7, medida de la inclinación de T1 (T1 slope), ángulo de la apertura torácica superior (TIA, thoracic inlet angle), la versión cervical (neck tilt), y línea de plomada de C7 hasta S1 (SVA C7-S1). Fue realizado análisis estadístico de los datos obtenidos para comprobar de forma objetiva la relación entre la alineación de la columna torácica en el plano sagital y el equilibrio sagital cervical de los portadores de escoliosis. Resultados: Treinta y cuatro pacientes eran mujeres (69,4\%) y 15 hombres $(30,6 \%)$. El promedio de los valores de COG-C7 fue 0,71 $\mathrm{mm}$ (mediana de 0,8 mm/desviación estándar $[D E]=0,51 \mathrm{~mm})$. Para el Cobb C2-C7 el promedio fue de $-11.7^{\circ}\left(\mathrm{mediana}\right.$ de $\left.-10^{\circ} / \mathrm{DE}=20,4^{\circ}\right)$. El promedio de inclinación de $T 1$ fue de $23,5^{\circ}$ (mediana de $25^{\circ} / D E=9.5^{\circ}$ ). El promedio de la versión cenvical fue de $58,8^{\circ}\left(\right.$ mediana de $60^{\circ} / D E=15,4^{\circ}$ ). El promedio del TIA fue de $81,8^{\circ}$ (mediana de $85^{\circ} / D E=16,7^{\circ}$ ). El promedio de la línea de plomada C7-S1 fue -0,28 (-0,3/DE=1,0). Conclusión: El análisis de los resultados obtenidos demostró que el promedio de los valores para la lordosis cervical es inferior a los valores normales como se describe en la literatura, lo que sugiere una pérdida de balance sagital cervical en estos pacientes.

Descriptores: Escoliosis; Balance postural; Columna vertebral.

Study conducted at the Universidade Estadual de Campinas (UNICAMP), School of Medical Sciences, Department of Orthopedics and Traumatology, Spine Surgery Group, Campinas, SP, Brazil.

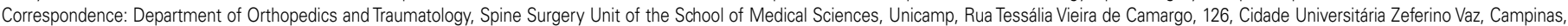
SP, Brazil. 13083-887. mrisso@mpc.com.br 


\section{INTRODUCTION}

Scoliosis is defined as a three-dimensional deformity in which the frontal plane has a lateral deviation of greater than 10 degrees. This deformity can involve asymmetry of the shoulders and of the carriage, the presence of a prominent costal hump in the convex region of the curve, and changes in sagittal balance. ${ }^{1}$

Multiple studies have analyzed the relationship between lumbar Iordosis and thoracic kyphosis. In idiopathic scoliosis, the decrease in thoracic kyphosis is associated with a decrease in lumbar lordosis. It should be noted, however, that although information about the relationship between thoracic kyphosis and lumbar lordosis has already been published in the literature, very little has been published about the reaction of the cervical spine to correction of deformity in idiopathic scoliosis. ${ }^{2}$

Hilibrand et al. ${ }^{3}$ were the first to confirm the radiographic relationship between cervical and thoracic alignment in the sagittal plane. They noticed an inverse relationship between thoracic kyphosis and cervical lordosis in idiopathic scoliosis, in other words, the less the thoracic kyphosis the greater the loss of cervical lordosis. In relation to the sagittal plane, a large percentage of patients with AIS present thoracic hypokyphosis and an inversion of cervical lordosis, changes that can influence the treatment and the postoperative quality of life of these patients. When not corrected, the inversion of the cervical lordosis can cause early degenerative changes, increasing the incidence of cervicalgia. ${ }^{2,4}$

Until very recently, the radiographic parameters of the sagittal balance of the cervical spine were typically inferred from a plumb line dropped from the seventh cervical vertebra and were not accurate in measuring the alignment of the cervical spine. ${ }^{2}$

There are no standard values for the evaluation parameters of cervical sagittal balance in patients with idiopathic scoliosis defined in the literature. This study seeks to describe the cervical sagittal parameters in patients with adolescent idiopathic scoliosis.

\section{METHOD}

This is a cross-sectional, retrospective, descriptive study conducted with information obtained from the medical records and the evaluation of lateral panoramic radiographs of 49 patients in outpatient follow-up at the Spine Service of the Hospital das Clínicas of the Unicamp School of Medical Sciences, who did not undergo surgical treatment. The study was duly approved by the Institutional Review Board and the approval opinion was registered as number 886.837 on November 24, 2014.

A quantitative evaluation of the data was performed using the Cobb method to measure $\mathrm{C} 2$ to $\mathrm{C} 7$ cervical lordosis, the distance from the center of gravity of the cranium (COG) to C7 (COG C0-C7) (Figures 1 and 2), the measurement of the T1 Slope, the thoracic inlet angle (TIA) (Figure 3), neck tilt (Figure 4), and the plumb line from C7 to S1 (SVA C7 - S1). The distribution of the parameters evaluated is shown in Table 1.

Cervical lordosis in C2 to C7 was evaluated by the Cobb method,

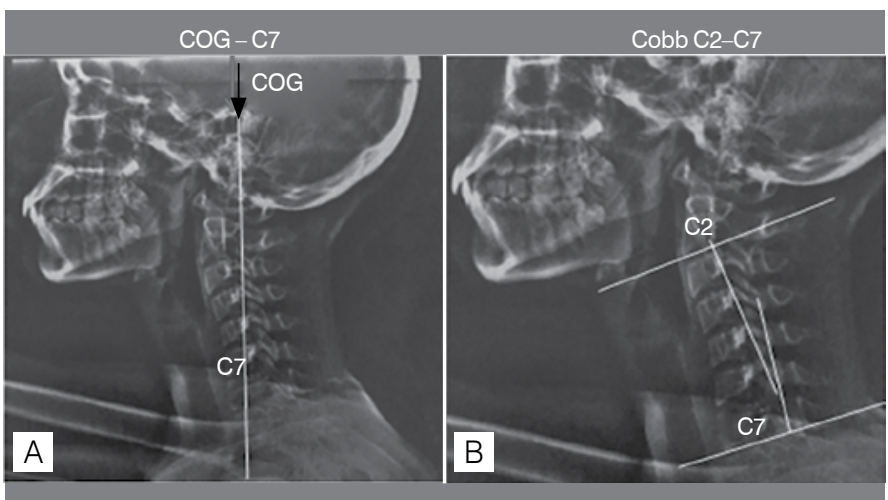

Figure 1. Representation of the COG-C7 (A) and Cobb C2 - C7 (B) parameters. which involves drawing four lines, the first parallel to the terminal plate of C2. The second line is drawn parallel to the terminal plate of $\mathrm{C} 7$. Then two lines are drawn perpendicular to the first two. The angle between these two perpendicular lines corresponds to the degree of cervical curvature. ${ }^{3}$

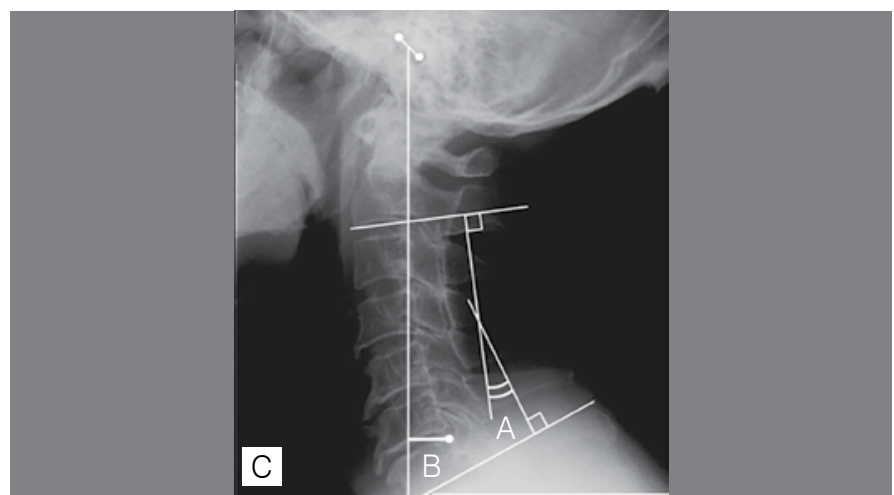

Figure 2. Schematic representation of the Cobb C2 - C7 (A) and COG-C7 measurements.

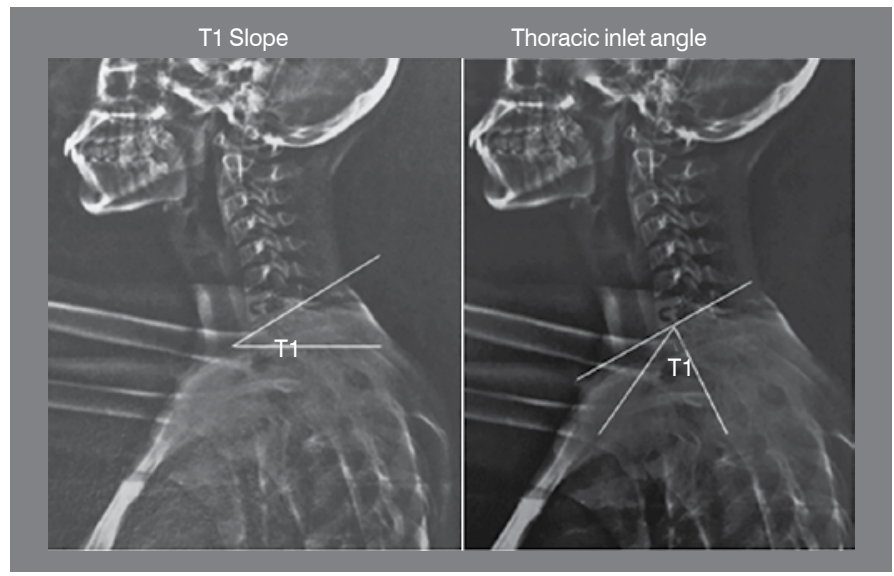

Figure 3. Representation of the T1 slope and TIA.

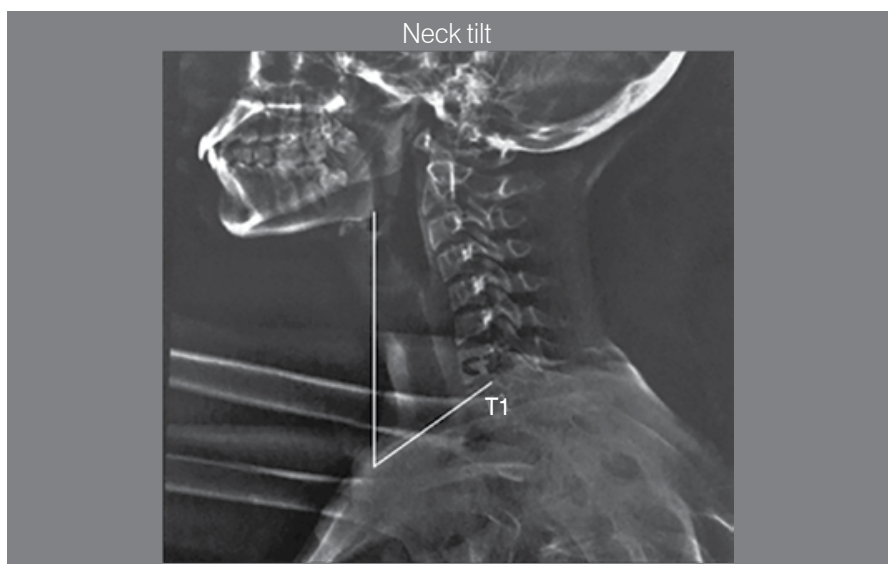

Figure 4. Representation of neck tilt.

Table 1. Parameters for the evaluation of cervical sagittal balance.

\begin{tabular}{c|c}
\hline \multicolumn{2}{c}{ Parameters evaluated } \\
\hline Distance from the center of gravity of the cranium to C7 & COG - C7 \\
\hline Cervical Cobb angle C2 - C7 & C2 - C7 \\
\hline T1 slope & T1 SLOPE \\
\hline Neck tilt & NECK TILT \\
\hline Thoracic inlet angle & TIA \\
\hline Plumb line from C7 - S1 & C7 - S1 SVA \\
\hline
\end{tabular}


The cervical SVA using the center of gravity of the head (COG) is calculated using the external ear as the point of the plumb line that will be associated with the line of $\mathrm{C} 7$ to measure the $\mathrm{COG}-\mathrm{C7}$ SVA distance. ${ }^{4}$

Neck tilt is defined as the angle between the two lines originating in the upper region of the sternum, one being vertical and the other connecting the sternum to the center of the terminal plate of $\mathrm{T} 1 .{ }^{4}$

The TIA is the angle between the perpendicular line drawn from the center of the terminal plate of $\mathrm{T} 1$ and a second line drawn from the center of the terminal plate of $\mathrm{T} 1$ to the upper region of the sternum. ${ }^{4}$

Another important angle is the T1 slope, which is drawn between the terminal plate of $\mathrm{T} 1$ and the horizontal plane. ${ }^{4}$ (Figure 5)

The sagittal translation of the spine is measured using a plumb line from $\mathrm{C} 7$ to S1 (SVA) and consists of a vertical line that descends from the center of the $\mathrm{C} 7$ vertebral body towards the ground, with the posterior upper edge of the plateau of S1 as a caudal reference. ${ }^{4}$ (Figure 6)

The results were distributed in tables and then a statistical analysis of the data obtained was performed to prove objectively the relationship between the alignment of the thoracic spine in the sagittal plane and the cervical sagittal balance of the patients.

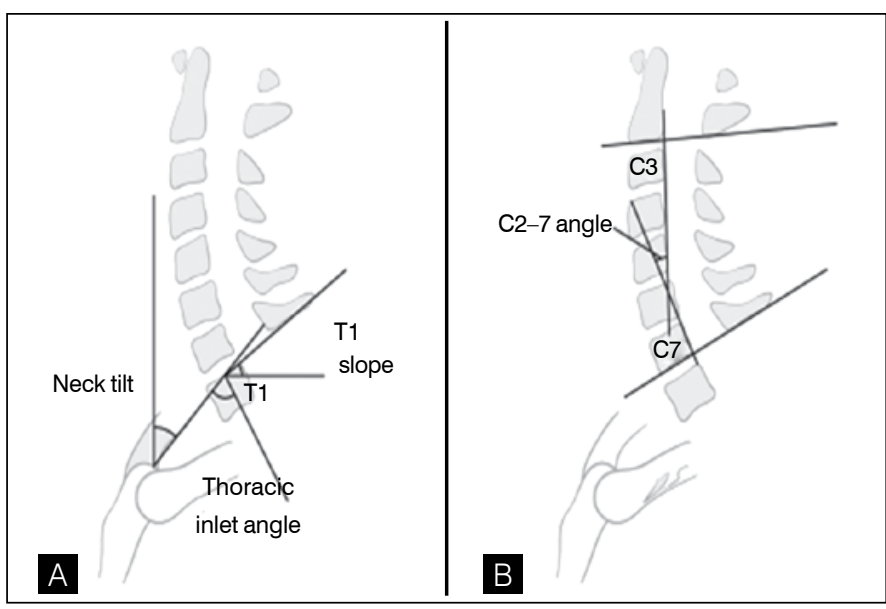

Figure 5. (A) Schematic design representing the measurement of T1 slope, TIA, and neck tilt; (B) Schematic design representing the measurement of cervical Cobb C2 - C7.

Source: Modification of Lafage V. Influence of spinal deformity and Outcome of cervical spondylitic myelopathy - Cervical Radiographical Alignment (Phila Pa 1976). 2013.

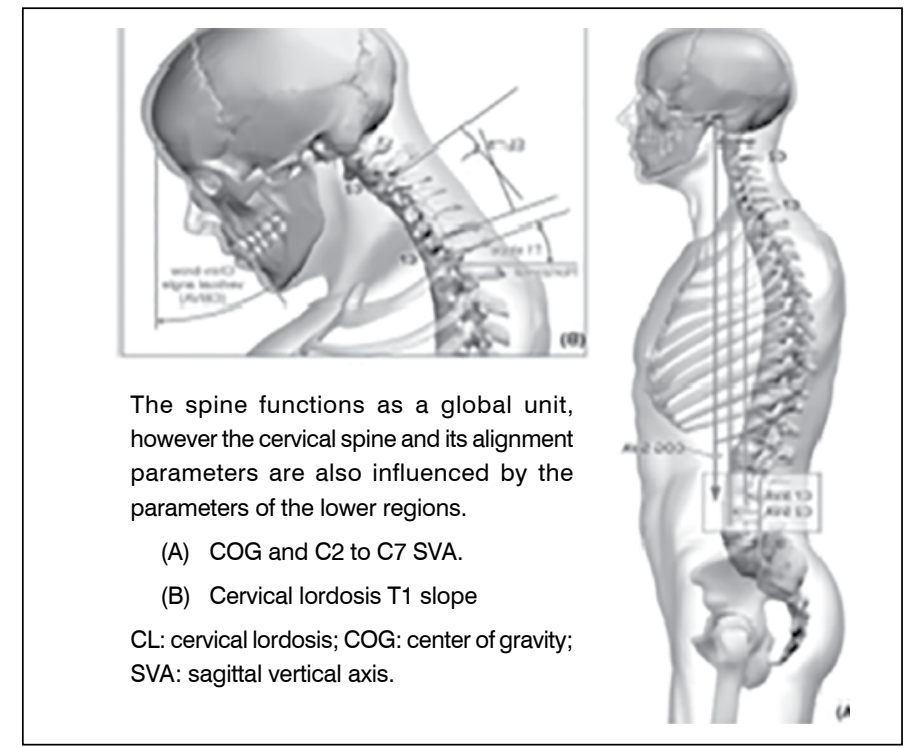

Figure 6. Representation of the cervical sagittal balance parameters,

Source: Modification of Lafage V. Influence of spinal deformity and Outcome of cervical spondylitic myelopathy - Cervical Radiographical Alignment (Phila Pa 1976). 2013.
The patient ages and the measurements of the parameters were described using summary measurements (mean, standard deviation, median, minimum, and maximum), while sex was described using absolute and relative frequencies. ${ }^{5}$

\section{RESULTS}

The panoramic lateral radiographs of 49 patients with adolescent idiopathic scoliosis were evaluated, 34 of them female (69.4\%) and 15 of them male (30.6\%).

We evaluated the cervical sagittal parameters and submitted them to statistical analysis, the results of which are displayed in Tables 2 and 3 .

Table 2. Statistical analysis of the cervical sagittal balance evaluation parameters.

\begin{tabular}{c|c|c|c}
\hline \multicolumn{4}{|c}{ Parameters evaluated } \\
\hline Name & Mean & Median & Standard Deviation \\
\hline COG - C7 & $0.71 \mathrm{~mm}$ & $0.8 \mathrm{~mm}$ & $0.51 \mathrm{~mm}$ \\
\hline Cobb C2 - C7 & $-11.7^{\circ}$ & $-10^{\circ}$ & $20.4^{\circ}$ \\
\hline T1 slope & $23.5^{\circ}$ & $25^{\circ}$ & $9.5^{\circ}$ \\
\hline Neck tilt & $58.8^{\circ}$ & $60^{\circ}$ & $15.4^{\circ}$ \\
\hline TIA & $81.8^{\circ}$ & $85^{\circ}$ & $16.7^{\circ}$ \\
\hline C7 - S1 SVA & $-0.28 \mathrm{~mm}$ & $-0.3 \mathrm{~mm}$ & $1 \mathrm{~mm}$ \\
\hline
\end{tabular}

Table 3. Detailed statistical analysis of the data and parameters evaluated.

\begin{tabular}{|c|c|c|c|}
\hline Variable & $\begin{array}{c}\text { Description } \\
(\mathrm{N}=49)\end{array}$ & Variable & $\begin{array}{c}\text { Description } \\
(\mathrm{N}=49)\end{array}$ \\
\hline \multicolumn{2}{|c|}{ Age (years) } & \multicolumn{2}{|c|}{ COG-C7 } \\
\hline $\begin{array}{l}\text { Mean (Standard } \\
\text { deviation) }\end{array}$ & $18.4(5.2)$ & $\begin{array}{c}\text { Mean } \\
\text { (Standard deviation) }\end{array}$ & $0.71(0.51)$ \\
\hline $\begin{array}{c}\text { Median } \\
\text { (min.; max.) }\end{array}$ & $17(10 ; 42)$ & $\begin{array}{c}\text { Median } \\
\text { (min.; max.) }\end{array}$ & $0.8(0 ; 2.5)$ \\
\hline \multicolumn{2}{|c|}{ Sex $n(\%)$} & \multicolumn{2}{|c|}{ C7-S1 SVA } \\
\hline Female & $34(69.4)$ & $\begin{array}{c}\text { Mean } \\
\text { (Standard deviation }\end{array}$ & $-0.28(1)$ \\
\hline Male & $15(30.6)$ & $\begin{array}{c}\text { Median } \\
\text { (min.; max.) }\end{array}$ & $-0.3(-2 ; 2)$ \\
\hline \multicolumn{2}{|c|}{$\begin{array}{l}\text { Value of the angle of } \\
\text { the principal curve }\end{array}$} & \multicolumn{2}{|c|}{ Cobb C2-C7 } \\
\hline $\begin{array}{c}\text { Mean (Standard } \\
\text { deviation) }\end{array}$ & $50.1(19.4)$ & $\begin{array}{l}\text { Mean (Standard } \\
\text { deviation) }\end{array}$ & $-11.7(20.4)$ \\
\hline $\begin{array}{c}\text { Median } \\
\text { (min.; max.) }\end{array}$ & $50(18 ; 95)$ & $\begin{array}{c}\text { Median } \\
\text { (min.; max.) }\end{array}$ & $-10(-55 ; 30)$ \\
\hline \multicolumn{2}{|c|}{$\begin{array}{l}\text { Cobb of the proximal } \\
\text { thoracic curve }\end{array}$} & \multicolumn{2}{|c|}{ T1 slope } \\
\hline $\begin{array}{l}\text { Mean(Standard } \\
\text { deviation) }\end{array}$ & $6.2(12.6)$ & $\begin{array}{c}\text { Mean (Standard } \\
\text { deviation) }\end{array}$ & $23.5(9.5)$ \\
\hline $\begin{array}{c}\text { Median } \\
\text { (min.; max.) }\end{array}$ & $0(0 ; 44)$ & $\begin{array}{c}\text { Median } \\
\text { (min.; max.) }\end{array}$ & $25(3 ; 40)$ \\
\hline \multicolumn{2}{|c|}{$\begin{array}{c}\text { Cobb of the principal } \\
\text { thoracic curve }\end{array}$} & \multicolumn{2}{|c|}{ Neck Tilt } \\
\hline $\begin{array}{c}\text { Mean (Standard } \\
\text { deviation) }\end{array}$ & $38.5(27)$ & $\begin{array}{c}\text { Mean (Standard } \\
\text { deviation) }\end{array}$ & $58.8(15.4)$ \\
\hline $\begin{array}{c}\text { Median } \\
\text { (min.; max.) }\end{array}$ & $45(0 ; 95)$ & $\begin{array}{c}\text { Median } \\
\text { (min.; max.) }\end{array}$ & $60(12 ; 95)$ \\
\hline \multicolumn{2}{|c|}{ Thoracolumbar/lumbar Cobb } & \multicolumn{2}{|l|}{ TIA } \\
\hline $\begin{array}{l}\text { Mean (Standard } \\
\text { deviation) }\end{array}$ & $33.3(25.2)$ & $\begin{array}{l}\text { Mean (Standard } \\
\text { deviation) }\end{array}$ & $81.8(16.7)$ \\
\hline $\begin{array}{c}\text { Median } \\
\text { (min.; max.) }\end{array}$ & $35(0 ; 88)$ & $\begin{array}{c}\text { Median } \\
\text { (min.; max.) }\end{array}$ & $85(22 ; 120)$ \\
\hline \multicolumn{4}{|c|}{ T1-T12 Kyphosis } \\
\hline $\begin{array}{c}\text { Mean (Standard } \\
\text { deviation) }\end{array}$ & $43.1(17.3)$ & & \\
\hline $\begin{array}{c}\text { Median } \\
\text { (min.; max.) }\end{array}$ & $40(5 ; 80)$ & & \\
\hline
\end{tabular}




\section{DISCUSSION}

The cervical spine is very complex as it allows a great range of motion and also supports the weight of the head. The complex nature of the cervical region makes it susceptible to a variety of disorders and complications, many of which can be caused by abnormal alignment or be accompanied by such alignment during the evolution of the pathology, sometimes requiring surgery to correct it. In addition, abnormalities in the cervical spine are usually very debilitating and have undesirable effects on the overall function of the individual and on their quality of life. The current cervical evaluation measurements do not sufficiently consider sagittal balance. The residual alignment from the occipital bone of C7, for example, is usually not taken into account in the evaluation of patients, even though it plays an important role in the balance of the individual. ${ }^{4}$

The principal method used to evaluate cervical lordosis is the Cobb method. It can measure lordosis from $\mathrm{C} 1$ to $\mathrm{C} 7$ and from $\mathrm{C} 2$ to $\mathrm{C} 7{ }^{2}$ Cervical lordosis is defined as a Cobb angle greater than $-2.5^{\circ}$ measured between the lower terminal plates of C2 - C7. Kyphosis is defined for a value of the Cobb angle greater than $2.5^{\circ}$. Patients with a Cobb angle between 2.5 and 5 degrees are considered to have a rectified cervical spine. ${ }^{4}$

The sagittal translation of the cervical spine is measured by means of a plumb line from C7-S1 (SVA), for which different measurement methods exist. Both the C2 and C7 SVAs have been used to calculate the sagittal alignment by measuring the distance between the C2 and C7 plumb lines and the line drawn in the upper posterior corner of the sacrum (Figure 5). Another form of calculation measures the distance between the two plumb lines, the first drawn from the center of C2 (DENS) and the second from the upper aspect of C7. A third form of calculating the SVA is by means of a line from the center of gravity (COG) of the head. In lateral radiographs, the COG of the head can be measured using the anterior portion of the external ear as the point of the plumb line that will be associated to the $\mathrm{C} 7$ line to measure the COG - C7 SVA distance. The average value of the COG - C7 SVA is defined as $43.6 \pm 23.7 \mathrm{~mm}^{4}{ }^{4}$

Recent studies have investigated several new cervical parameters. Lee introduced the concept of the angle between the neck tilt and the thoracic angle inlet (TIA). A relationship was determined defining the TIA as the value equal to the sum of the T1 slope and the neck tilt $(\mathrm{TIA}=\mathrm{T} 1$ slope $+\mathrm{NT}) \cdot{ }^{4}$

The correlation between these variables also indicates that a lower TIA creates less of a T1 slope in order to maintain physiological neck tilt and vice-versa. The TIA and the T1 slope can be used as parameters to assess sagittal balance, predicting physiological alignment and guiding the correction of the cervical spine deformity. The T1 slope determines the quantity of subaxial lordosis required to maintain the center of gravity of the head in a position of balance and varies according to the overall sagittal balance of the spine, in relation to the C7 - S1 SVA and the kyphosis present in the thoracic spine. ${ }^{4}$

The C7 - S1 SVA is commonly recognized as the gold standard for evaluating the overall sagittal balance of the individual. However, it does not take cervical alignment, which seems to be of paramount importance to sagittal balance, into account. Few studies have described the relationship between $\mathrm{T} 1$ and the overall sagittal balance of the spine. In the study by Lee et al. apud Ponsenti et al. ${ }^{6}$ the T1 slope was closely linked to the overall sagittal balance of the spine and also to the degree of the cervical lordosis of the patients.

According to Janusz et al., ${ }^{7}$ the average TIA, T1 slope, and neck tilt values are $71.7 \pm 9.5,26.7 \pm 6.3$, and $44.9 \pm 7.2$, respectively.

Because studies of sagittal balance are recent, there is not yet consensus around these values in the literature. The TIA, T1 slope, and neck tilt values according to Weng et al. ${ }^{8}$ are 78.0, 33.2, and 44.88, respectively. The average C2 - C7 Cobb angle is 15.4 and the C2 - C7 SVA is $22 \mathrm{~mm}^{9}$

The data obtained in our study showed an increase in the COG - C7 as compared to the values in the literature, with a tendency for the forward projection of the skull in patients with idiopathic scoliosis. It was also possible to confirm that the cervical lordosis values were closer to the lower limit of normality, showing a tendency towards rectification of spinal lordosis. The neck tilt and thoracic inlet angles presented higher values than those found in the literature, ${ }^{4,9,10}$ due to the modification of the cervical position in relation to the region of the cervicothoracic transition.

Finally, the C7 - S1 SVA C7-S1 (C7 - S1 plumb line) had a value lower than that published in the literature.

The radiographic analysis conducted in this study demonstrated a tendency towards the loss of cervical sagittal balance in patients with idiopathic scoliosis, which was confirmed by the tendency towards a decrease of cervical lordosis and the modification of the cervical parameters in relation to the reference values in the literature.

\section{CONCLUSION}

Our analysis of the results showed that the average cervical lordosis values found were less than those described as normal in the literature, suggesting a loss of cervical sagittal balance in these patients.

All the authors declare that there are no potential conflicts of interest regarding this article.

CONTRIBUTIONS OF THE AUTHORS: Each author made significant individual contributions to the development of the manuscript. MCL, MIRN, and PTMC contributed to the writing of the manuscript, the analysis of the data, and the statistical analysis. MCL contributed to data collection. GRZ, IGV, MAT, WP, MCL, PTMC, and MIRN collaborated in discussions about the data. MIRN and PTMC performed the final review of the manuscript. EL, MIRN, and PTMC contributed to the intellectual concept of the study.

\section{REFERENCES}

1. Cowell HR, Hall JN, MacEwen GD. Genetic aspects of idiopathic scoliosis. A Nicholas Andry Award essay, 1970. Clin Orthop Relat Res. 1972;(86):121-31.

2. Hwang SW, Samdani AF, Tantorski M, Cahill P, Nydick J, Fine A, et al. Cervical sagittal plane decompensation after surgery for adolescent idiopathic scoliosis: an effect imparted by postoperative thoracic hypokyphosis. J Neurosurg Spine. 2011;15(5):491-6.

3. Hilibrand AS, Tannenbaum DA, Graziano GP, Loder RT, Hensinger RN. The sagittal alignment of the cervical spine in adolescent idiopathic scoliosis. J Pediatr Orthop. 1995;15(5):627-32.

4. Ames CP, Blondel B, Scheer JK, Schwab FJ, Le Huec JC, Massicotte EM, et al. Influence of spinal deformity on management and Outcome of cervical spondylotic myelopathy Cervical radiographical alignment: Comprehensive assessment techniques and potential importance in cervical myelopathy. Spine. 2013;38:s149-s160

5. Kirkwood BR, Sterne, JAC. Essential medical statistics. 2nd ed. Massachusetts, USA: Blackwell Science; 2006.

6. Pesenti S, Blondel B, Peltier E, Choufani E, Bollini G, Jouve JL. Interest of T1 parameters for sagittal alignment evaluation of adolescent idiopathic scoliosis patients. Eur Spine J. 2016;25(2):424-9

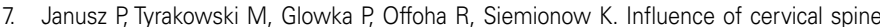
position on the radiographic parameters of the thoracic inlet alignment. Eur Spine $J$. 2015;24(12):2880-4.

8. Weng C, Wang J, Tuchman A, Wang J, Fu C, Hsieh PC, et al. Influence of T1 slope on the cervical sagittal balance in degenerative cervical spine: An analysis using Kinematic MRI. Spine (Phila Pa 1976),2016;41:185-190.

9. Legarreta CA, Barrios C, Rositto GE, Reviriego JM, Maruenda JI, Escalada MN et al. Cervical and thoracic sagittal misalignment after surgery for adolescent idiopathic scoliosis: a comparative study of all pedicle screws versus hybrid instrumentation. Spine (Phila Pa 1976). 2014;39(16):1330-7.

10. Knight RQ, Jackson RP, Killian JT, Stanley EA. (2010) Scoliosis Research Society: White Paper on Sagittal Plane Alignment. Scoliosis Research Society www.srs.org/profissonals. Accessed 03/03/2015. 